УДК 631.42

(C) 2013

Коваль В. В., директор,

Наталочка В. О., завідувач лабораторією екологічної безпеки земель та якості продукції,

Ткаченко С. К., завідувач лабораторією експериментальних досліджень, проектно-технологічної документації та інформаційного забезпечення, Міненко О. В., завідувач лабораторією агрохімічної паспортизації земель, моніторингу та охорони родючості трунтів

Полтавський обласний державний проектно-технологічний центр охорони родючості грунтів і якості продукції

\title{
СУЧАСНИЙ СТАН ЗАБЕЗПЕЧЕНОСТІ ГРУНТІВ ПОЛТАВСЬКОЇ ОБЛАСТІ БОРОМ
}

\section{Рецензент - кандидат сільськогосподарських наук В. В. Ляиенко}

Наведено результати багаторічних досліджень $i$ узагальнено сучасний стан родючості земель сільськогосподарського призначення Полтавської області. Проаналізовано динаміку забезпечення грунтів Полтавської області бором та надані рекомендації щзодо подальшого призупинення їх деградаиії, а також відновлення родючості. Лабораторними дослідженнями протягом 2001-2010 років визначено, щзо вміст бору в трунтах області за два останні тури обстеження суттєво не змінився. За даними VIII туру обстеження, середній вміст бору становить 1,05 мг/кг трунту проти 1,11 мг/кг у IX mурі.

Ключові слова: моніторинг трунтів, трунт, агрохімічні показники, родючість трунту, бор, мікроелементи.

Постановка проблеми. Вміст рухомої форми бору в грунтах України коливається від мінімальної (слідової) кількості в дерново-підзолистих супіщаних грунтах Полісся до 3,37 мг/кг грунту - у чорноземах солонцюватих. Грунти Полісся необхідно віднести до грунтів із вираженим дефіцитом бору, дерново-підзолисті поверхнево оглеєні грунти Карпат віднесено до групи із середнім вмістом бору $-0,3-0,5 \mathrm{мг} / к \Gamma$ грунту. Грунти Лісостепу 3 вмістом бору 0,18-2,30 мг/кг грунту віднесено до групи з високим вмістом цього елемента [5]. Агрохімічний моніторинг, проведений Інститутом грунтознавства та агрохімії ім. А. Н. Соколовського УААН, засвідчив, що $25 \%$ ріллі має низький вміст і дефіцит бору. Загальний вміст бору в різних типах грунтів може сягати від 1-2 до 50-80 мг/кг грунту. У грунтах Полісся його фоновий вміст, у середньому, становить 8 мг/кг грунту. В окремих грунтах вміст бору може становити до 1,5 мг/кг, що навіть нижче порогової концентрації. У зоні Лісостепу фоновий вміст бору становить 6-12 мг/кг. У грунтах зони Степу бору дещо більше, ніж у Лісостепу - його вміст становить 10-11 мг/кг грунту. Найкраще забезпеченні бором солонцюваті грунти. Коефіцієнт засвоєння бору із грунту становить лише 3-10\%, що залежить від цілої низки чинників (кислотність грунту, вологість, вміст органічної речовини, гранулометричний склад грунту, високий вміст кальцію та калію). Гумусонакопичення відіграє не останню роль у накопиченні рухових форм мікроелементів у грунті і спостерігається зворотній зв'язок з агрохімічною оцінкою землі. За збільшення гумусу у 2,9 рази процес накопичення мікроелементів протікає від 1 до 1,8 разів повільніше, тобто вміст мікроелементів змінюється під впливом комплексу факторів, одним 3 яких $є$ гранулометричний склад. Безпосереднє використання мікроелементів і регуляторів розвитку в умовах із різною кількістю фізичної глини дає приріст урожайності до 30 \%, що спостерігається по всіх варіантах із застосуванням позакореневого підживлення [1]. Тривале застосування одних тільки мінеральних добрив, як окремо взятий агрозахід, знижує загальний рівень ефективної родючості грунтів. Підвищення доз мінеральних добрив у три рази протягом другої ротації сівозміни змінює рівень забезпеченості мікроелементами й, відповідно, зведеного показника якості грунту [4]. Бор сприяє споживанню кальцію рослинами 3 грунту. Дефіцит бору у грунті погіршує споживання кальцію рослинами за його високого вмісту. У разі високого забезпечення грунту калієм потреби культур у борі різко зростають. Для точної оцінки подібних перетворень і здійснення спрямованого регулювання грунтових процесів виникла потреба в організації систематичних спостережень за ними, тобто, в організації служби моніторингу. Нині єдиною державною організацією, що веде регулярні моніторингові спостереження за станом родючості грунтів, є ДУ «Державний науковотехнологічний центр охорони родючості грунтів», в областях - центри «Облдержродючість», які виконують роботи 3 агрохімічної паспортизації земель (циклічність - раз у п'ять років). У ДУ Полтавський центр «Облдержродючість» нагромадив- 


\section{СІЛЬСЬКЕ ГОСПОДАРСТВО. РОСЛИННИЦТВО}

ся значний матеріал стосовно агрохімічної характеристики двадцятисантиметрового (орного шару) грунтового покриву сільськогосподарських угідь області.

Аналіз основних досліджень і публікацій, у яких започатковано розв'язання проблеми. Джерелом бору є мінерали, а також атмосферні опади, які несуть із собою бор викидів промислових підприємств або піднятих в атмосферу крапель морської води (прибережна зона морів). Наприклад, кількість бору, який вноситься в грунти Польщі з атмосферними опадами, в середньому становить: у сільськогосподарських районах - 24 г/га, в приморських - 41 г/га, а в промислових - 142 г/га. Значна частина бору вноситься 3 добривами та 3 препаратами захисту рослин; рослини споживають бор у вигляді борної кислоти. Кількість вживаного бору залежить від виду рослин і становить у середньому 100 г/га (можливі коливання від 60 до 600 г/га). Найвищий вміст бору в овочевих культурах виявлено у капусті і шпинаті, а у фруктових - у яблуках і цитрусових. На відміну від інших мікроелементів, роль бору у фізіологічних процесах не повністю з'ясована. Відома його участь у будові клітин. Нестача бору негативно впливає на формування меристеми. Достатня його наявність у грунті позитивно впливає на цвітіння і плодоношення. Нестача бору зумовлює некрози надземних частин і коріння (наприклад, цукрового буряка), відмирання ростових бруньок, в'янення листя і хлороз, сповільнення росту коріння. До ознак нестачі бору належить і таке явище як утворення шкаралупи на яблуках. Хвороби, зумовлені нестачею бору, трапляються часто в рослин, які ростуть на грунтах із малим вмістом бору або ж на кислих легких грунтах вологого клімату [3]. Достатнє забезпечення бором - основа для високих врожаїв насіння і плодів, а також для підвищення морозостійкості окремих плодових дерев (черешня, персики). Нестача бору може негативно вплинути на якість урожаю. Наприклад, коріння салери буріє і втрачає смакові якості, бульбини картоплі стають дрібними, мають потріскану поверхню і буруваті всередині. Шкідливою для рослин є й надлишкова концентрація бору в грунті. Отруєння бором рослин виявляється в побронзовінні листя, часто лише країв листкової пластинки; у випадку більшої концентрації бору рослина всихає. Хворі рослини містять значну кількість бору. Шкідливий вплив бору можна зменшити шляхом вапнування грунтів. Немає даних про якийсь вплив бору на тварин. Однак добра якість плодів, які ми вживаємо, значною мірою залежить від його участі.
Мета досліджень. Метою досліджень було вивчення, оцінка забезпеченості та зміни в часі грунтового покриву Полтавської області за останні два тури агрохімічного обстеження (VIII - 20012005 pp. i IX - 2006-2010 роки) бором.

Завдання досліджень. Літературний аналіз засвідчив, що питання про вміст в грунтах мікроелементів, і зокрема бору, на Полтавщині на сьогодні лишається вкрай маловивченим. Це й послугувало достатньою підставою для проведення досліджень стосовно вмісту в грунтах Полтавської області бору і його динаміки у часі в умовах даного регіону.

Матеріали і методи досліджень. Об'єктом досліджень було вивчення забезпеченості грунтів Полтавської області бором. Матеріалом для проведення досліджень були зразки грунту, які з 2001 року по 2010 рік відбиралися спеціалістами ДУ Полтавський центр «Облержродючість» на території сільськогосподарських формувань Полтавської області. Дослідження даних зразків проводилося згідно з ОСТ 10150-88 в 0,1\% $\mathrm{MqSO}_{4}$ екстрагуючому розчині.

Результати досліджень. Дослідження проводилися атестованою спеціалізованою аналітичною випробувальною лабораторією, оснащеною сучасними засобами вимірювальної техніки, випробувальним обладнанням, а також висококваліфікованими фахівцями, атестованими з правом пробопідготовки та виконання вимірювань. Хімікоаналітичні дослідження виконувалися згідно з офіційно затвердженими методиками. Сільськогосподарські культури споживають бор протягом усього періоду вегетації. Під впливом бору поліпшується синтез і транспортування вуглеводів, ростових речовин (гормонів, РНК, ДНК) та аскорбінової кислоти 3 листків у генеративні органи та до коренеплодів. Бор потрібний рослинам для росту та розвитку меристемних тканин. Зауважимо, що сільськогосподарські культури споживають бор протягом усього періоду вегетації. Середні виноси бору (B) врожайністю коренеплодів цукрових буряків 80-100 ц/га - 80-90 г/га, а насінням ріпаків 8-10 ц/га - 100-120 г/га, насінням соняшнику 1012 ц/га - 120-160 г/га.

Нестача бору у рослинах призводить до руйнування молодих тканин, призупинення росту кореневої системи, стебла та відмирання точок росту у рослин. Бор сприяє проростанню пилку у пилкових трубках, запиленню квіток та плодоношенню. Дефіцит бору в грунті призводить до прихованого дефіциту бору рослин та появи низки небезпечних хвороб: вершкового хлорозу точок росту, сухої гнилі коренеплодів, гнилі сердечника, верхівкової виразки головки коренеплодів цукрових буряків. 


\section{СІЛЬСЬКЕ ГОСПОДАРСТВО. РОСЛИННИЦТВО}

У разі дефіциту бору на посівах ріпаку коренева система деформується, з'являються некротичні цятки, уповільнюється ріст точок росту, розтріскуються стебла, призупиняється цвітіння та погіршується перезимівля озимого ріпаку. Слід вказати, що фізіологічні захворювання, викликані дефіцитом бору, неможливо усунути іншими речовинами, зокрема фунгіцидами [2]. Аналіз одержаних результатів свідчить, що землі обстежених районів за вмістом бору практично відносяться до двох класів: землі з середньою та високою забезпеченістю (за винятком 11 тис. га в VIII турі та 17,3 тис. га в IX турі з низькою забезпеченістю). До середньої забезпеченості відносяться грунти на площі 362,9 тис. га, до високої - 689,6 тис. га в IX турі обстеження і, відповідно, 147 тис. га і 811,6 тис. га - в VIII турі агрохімічного обстеження. Середньозважений показник по області становить 1,05 мг/кг грунту. Зниження до попереднього туру становить 0,06 мг/кг грунту.

Даним показником можна знехтувати як похибкою, що допускається у визначенні даного елемента. Дещо зменшився середньозважений вміст бору в Великобагачанському (з 1,19 до 0,87 мг/кг грунту), Глобинському (з 1,27 до 0,84 мг/кг грунту), Диканському (з 1,02 до 0,91 мг/кг грунту), Карлівському (з 1,35 до 1,10), Кобеляцькому (з 1,19 до $1,01)$, Козельщанському (з 1,18 до 1,09), Оржицькому (з 1,42 до 0,81), Пирятинському (з 1,02 до $0,85)$, Семенівському (3 1,21 до 0,96$)$ районах. Найбільше зниження вмісту бору в грунті спостерігається на землях сільськогосподарських формувань Котелевського $(-0,5)$, Глобинського $(-0,43)$, Оржицького $(-0,61)$, Решетилівського $(-0,47)$ районів. Найвищий показник забезпеченості цим елементом - у грунтах Хорольського району (середньозважений показник $-1,77$ мг/кг грунту) і спостерігається найбільше підвищення вмісту бору (вміст за п'ять років збільшився на 0,43 мг/кг грунту). Взагалі вміст бору за останні 10 років залишається стабільним.

\section{БІБЛІОГРАФІЯ}

1. Греков В. О., Дацько Л. В., Жилкін В. А. [та ін.]. Грунт - основа життя. - К. : Мінагрополітики, Центрдержродючість. - 2010. - $178 \mathrm{c}$.

2. Гудзь В. П., Лісовал А. П., Андріснко В. О., Рибак $M . \Phi$. Землеробство з основами грунтознавства і агрохімії : Підручник / За ред. В. П. Гудзя. - Друге вид., перероб. та доп. - К. : Центр учбової літератури, 2007. $-408 \mathrm{c}$.

3. Кучерявий В. П. Екологія. - Львів : Світ,
Висновки: 1. Орні землі Полтавської області добре забезпечені бором.

2. Без мікроелементів принципово неможливе повноцінне засвоєння основних добрив (азоту, фосфору і калію) рослинами. Нестача мікроелементів порушує обмін речовин та хід фізіологічних процесів у рослині. Мікроелементи сприяють синтезу в рослинах повного спектру ферментів, що дають змогу інтенсивніше використовувати енергію, воду та макроелементи.

3. Лише завдяки збалансованому застосуванню добрив, що містять мікроелементи, можна отримати максимальний урожай належної якості, що генетично закладений у насінні сільськогосподарських культур. Нестача мікроелементів у доступній формі у грунті призводить до зниження швидкості протікання процесів, що відповідають за розвиток рослин. У кінцевому результаті це призводить до втрат урожаю, його класності та незадовільних органолептичних властивостей.

4. Кількість мікроелементів у грунті постійно зменшується шляхом їх засвоєння та виносом вирощеною продукцією та бур'янами. Зі зменшенням внесення органіки в грунт ми майже припинили їх природне поповнення.

5. Інколи нестача кількох десятків грамів одного 3 мікроелементів обмежує засвоєння інших елементів живлення й призупиняє зростання врожаю навіть на високих фонах живлення макроелементами. Найважливішими мікроелементами для неї $\epsilon$ марганець, молібден, мідь, цинк, бор. Їх вносять у грунт разом із мінеральними добривами, а також позакореневим підживленням та передпосівним обробленням насіння солями мікроелементів.

6. За умови високого рівня $\mathrm{pH}(>7,5)$ утворюється борат $-\mathrm{B}(\mathrm{OH})_{4}-\mathrm{i}$ бор переходить у недоступний для рослини стан. Він утворює стійкі сполуки із залізом та алюмінієм, органічною речовиною та глинистими мінералами грунту. Надмірне застосування меліорантів, які підвищують рівень $\mathrm{pH}$, може створити умови, за яких бор буде недоступним.

2001. -500 с. : іл.

4. Моніторинг комплексної оцінки родючості грунтів Полтавської області 1971-2005 pp. / За ред. Т. О. Грінченка. - Х., 2008. -185 с.

5. Присяжнюк М. В., Мельник С. І., Жилкін В. А. [та ін.]. Національна доповідь про стан родючості грунтів України. - К. : Мінагрополітики, Центрдержродючість, НААНУ, ННЦ ІГА ім. О. Н. Соколовського, НУБіП. - 2010. - 113 с. 